\title{
“Contested Peripheries" in World Systems Theory: Megiddo and the Jezreel Valley as a Test CASE*
}

Eric H. Cline

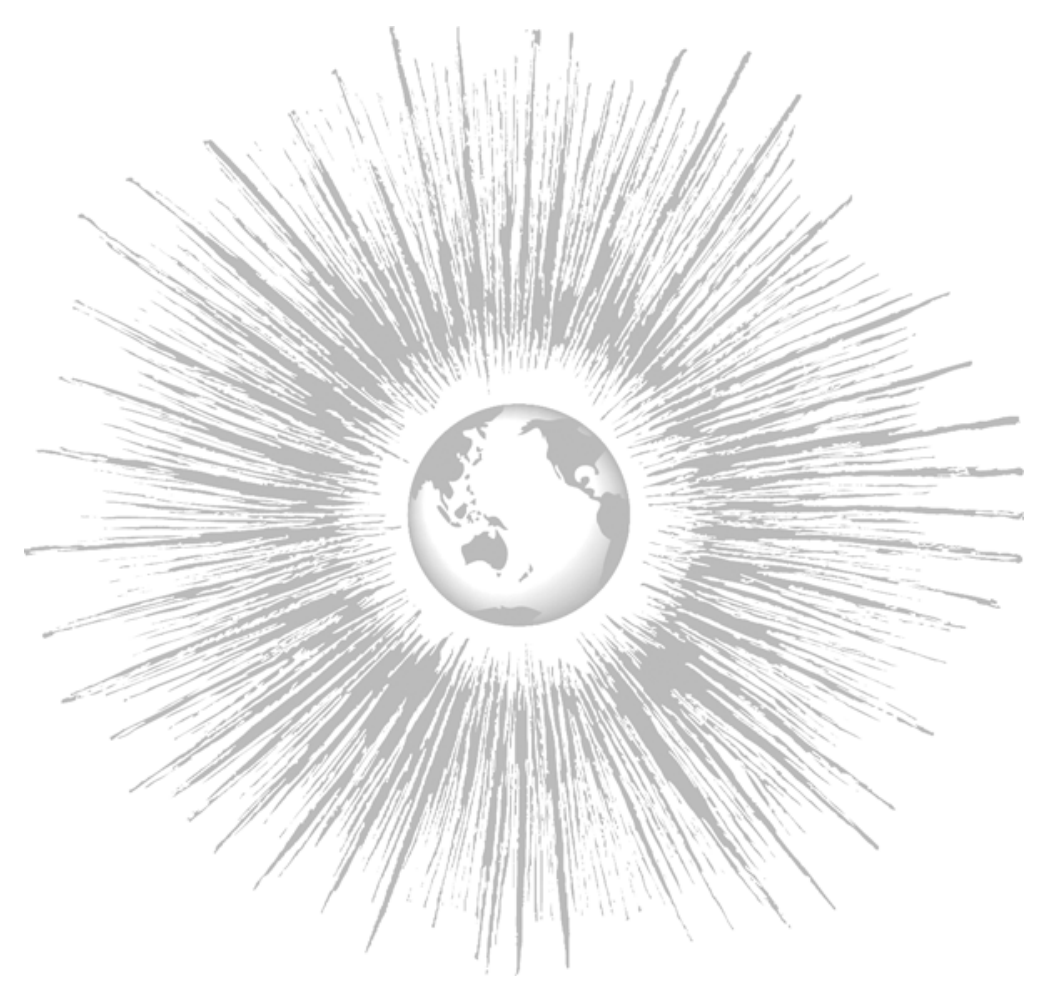

he term "contested periphery" was recently coined by Mitchell Allen for use in his 1997 UCLA dissertation concerned with Philistia, the NeoAssyrians, and World systems theory (Allen 1997: 49-51, 320-21, Fig. 1.4; cf. also Berquist 1995a, 1995b). Allen identified "contested peripheries" as "border zones where different systems intersect" (Allen 1997: 320). Chase-Dunn and Hall immediately adopted this term and defined it more formally as " $a$ peripheral region for which one or more core regions compete" (Chase-Dunn and Hall 1997: 37).

We may consider the term "contested periphery" as having geographical, political, and economic implications, since the affected region lies between two larger empires, kingdoms, or polities established to either side of it. For example, Allen convincingly argues that the area of Philistia in SyriaPalestine is an excellent example of a "contested periphery" during the NeoAssyrian period in the early first millennium BCE, for at that time Philistia was a region on the edge of the Egyptian world-system as well as on the fringe of the Assyrian world-system, and was an area desired by both the Egyptians and the Neo-Assyrians.

* I am grateful to Thomas Hall, Mitchell Allen, Nick Kardulias, Ian Morris, and Michael Sugerman for their valuable insights and feedback regarding this article, and to Louise Hitchcock for the opportunity to present a preliminary version in the "Theoretical Approaches to Near Eastern Archaeology" session at the 1999 annual meetings of the American Schools of Oriental Research, held in Cambridge, MA. Much of the hard data on the battles fought in the Jezreel Valley, presented as background evidence in this article, is taken from Cline 2000 (passim); a more popularizing version of this article will be published in Near Eastern Archaeology. The map was drawn by Robert Hagerty of Raymond Walters College at the University of Cincinnati.

JOURNAL OF WORLD-SYSTEMS RESEARCH, VOL VI, I, SPRING 2000, 7-I6 http://jwsr.ucr.edu/ 
Figure 1: Syria-Palestine in the Bronze and Early Iron Ages (Second and early first millennia BC

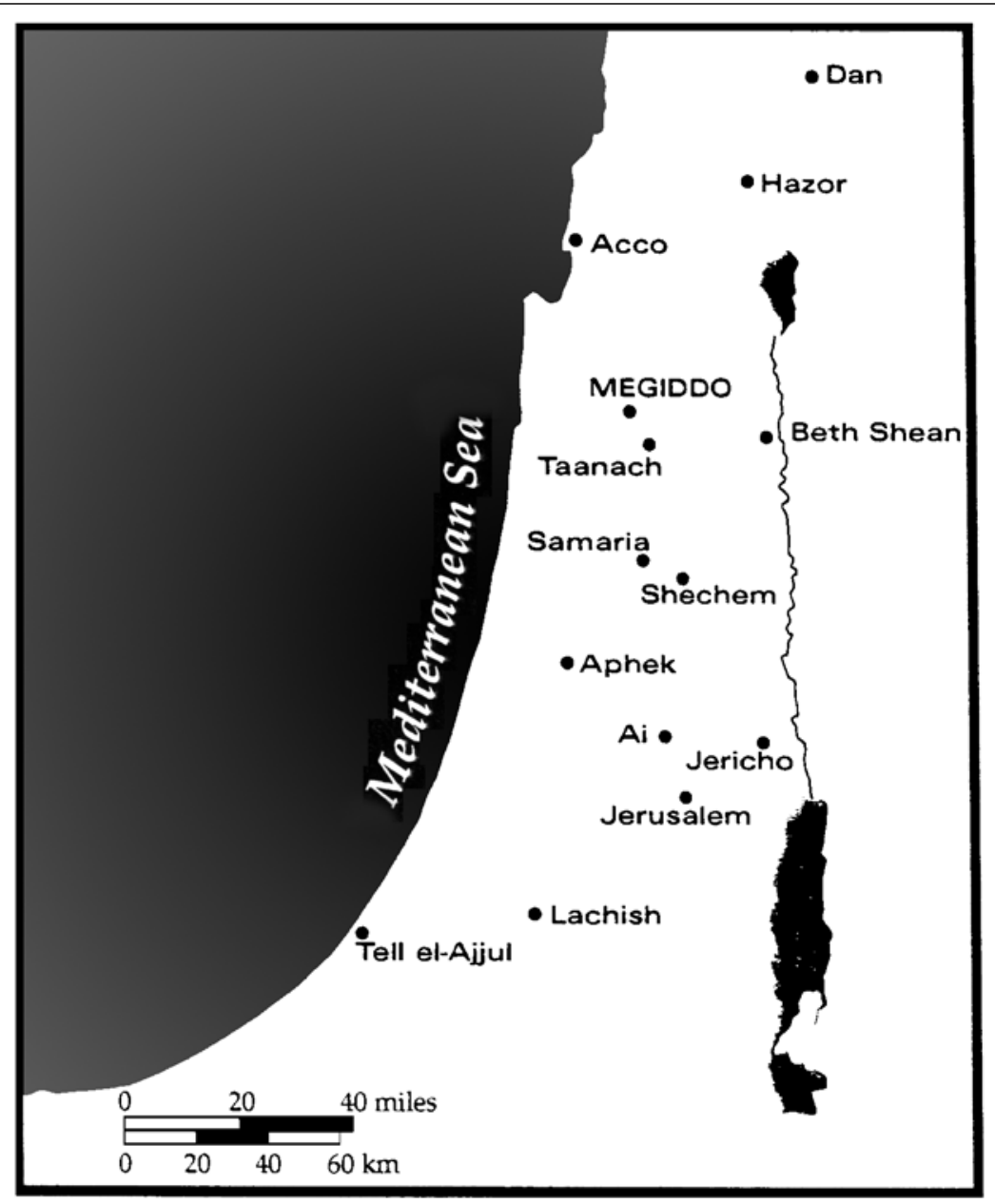

I would propose that "contested peripheries" are also likely to be areas of intense military activity, precisely because of their geographical locations and constantly-changing political affiliations. Thus, Allen's newly-coined phrase may be especially usefully applied to the area of Megiddo and the Jezreel Valley in northern Israel. This region has been a "contested periphery" for more than half of its bloody history. Of the 34 battles which have been fought at Megiddo or in the Jezreel Valley during the past 4,000 years by Canaanite, Egyptian, Greek, Roman, Byzantine, Islamic, Crusader, Mongol,
“Contested Peripheries" in World Systems Theory

Mamluke, Ottoman, Palestinian, French, and Allied forces, at least seventeen have been fought because this valuable and strategic area was in an unwelcome geographical predicament - a contested region situated on the periphery of two different and more-powerful world systems.

Megiddo is located in the Jezreel Valley, almost exactly halfway between Haifa on the Mediterranean coast to the west and Tiberias on the Sea of Galilee to the east, and between Egypt to the south and Mesopotamia to the north. The valley, also known as the Plain of Esdraelon (Esdraelon being the Greek modification of Jezreel), is shaped approximately like a triangle lying on its side, with its tip touching the Plain of Acco at the west and its bottom facing the Jordan River to the east. It runs nearly across the breadth of Israel, connecting the coastal region with the Jordan Valley, and lies at the juncture of several major military and trade routes, including one of the most important roads in the ancient world, the Via Maris. This was an international highway running between Egypt in the south and Syria, Phoenicia, Anatolia and Mesopotamia in the north and east. Sitting astride this chief north-south trade route, as it came through the Musmus Pass (Wadi Ara) and meandered through the Jezreel Valley, Megiddo had great strategic significance, for whoever controlled the city and maintained an army there would dominate this vital international route. It is not surprising, therefore, that nearly every force invading this area of Syria-Palestine from ca. 2350 BC to AD 2000 has fought a battle in the Jezreel Valley.

Designating Megiddo and the Jezreel Valley as a "contested periphery" finally provides a concise name for an observation that historians have been making about the region of Israel/Palestine as a whole, and this area in particular, for more than a century. Fisher, one of the excavators of Megiddo, perhaps said it best back in 1929;

"It has long been obvious to all historians that Palestine is a middle ground, a kind of ancient 'No-Man's Land,' lying between the great military powers encamped on either side of it-in Africa the great civilization of the Egyptian Pharaobs; in Asia the kings of Babylonia, the mighty armies of the Assyrian military empire, or the Macedonian rulers of the East. The armies of these great powers, whether marching from Asia into Africa or the reverse, passed up and down the valleys of Palestine ... The famous plain...taking its name from Megiddo (Armageddon) or from Esdraelon (Jezreel), thus became a battlefield where the great powers of neighboring Africa and Asia met in one long struggle after another for thousands of years, to dispute the political supremacy of the Near East. It was inevitable that there should grow up here a stronghold which would command the pass and the plain" (Fisher 1929: vii-viii). 
Now, with the application of Allen's term "contested periphery" to this region, Fisher's lengthy description may be reduced to a single sentence: "Megiddo, and the Jezreel Valley as a whole, was a 'contested periphery' throughout much of its history."

The Jezreel Valley region does not qualify as a "contested periphery" during the third, second, or even the very early first millennia BC, for during these periods the region does not meet the necessary criteria: namely, there are not two empires, kingdoms, or polities contesting the area, both of which claim the region as lying on its real or imagined periphery, but neither of which has people actually living in the area under dispute. During the second millennium BC, the flanking rival empires which were competing for military, economic, and political control of Syria-Palestine were the Egyptians and the Hittites, but they consistently fought further north, in the region of Kadesh and even as far as Ugarit in northern Syria. This is primarily because Egypt was in fairly firm control of southern Syria-Palestine during the second millennium, at least up until the time of Ramses II and perhaps beyond. Even with the advent of the Israelites and their quest for control of Canaan in the late second and early first millennia BC, the Jezreel Valley does not yet become a "contested periphery," because the Canaanites, and then the Philistines, can be considered local inhabitants fighting to retain control of their land against the invading Israelites.

I would propose that Megiddo and the Jezreel Valley first became a"contested periphery" in the mid-first millennium BC, during the Neo-Assyrian period and on through the ensuing Neo-Babylonian and Persian periods, when the region was criss-crossed time and again by armies intent on invading Egypt. This both complements and augments Allen's original use of the term in his discussion of Philistia as a "contested periphery" on the edges of the Egyptian and Neo-Assyrian world-systems. The Neo-Assyrian king Esarhaddon probably marched right past Megiddo during his successful campaign against Egypt in $671 \mathrm{BC}$. The dreaded Neo-Babylonian king Nebuchadnezzar, who had marched by the Jezreel Valley in 597 and 586 $\mathrm{BC}$, probably came through the area again during his attempted invasion of Egypt in 569 BC. The Persian king Cambyses undoubtedly also marched through the region while on his way to conquer Egypt in 526 BC. However, it is the meeting between Josiah, King of Judah, and the Egyptian Pharaoh Necho II in 609 BC, just before the end of the Kingdom of Judah and the beginning of the Babylonian Exile, which might perhaps be seen as the very first example of a conflict in which blood was actually spilled because the Jezreel Valley was a "contested periphery." Josiah was King of Judah, not of Israel, and Necho II's meeting with Josiah at Megiddo was essentially incidental to the Egyptians' real destination of Carchemish in North Syria, where they were heading to assist the Assyrians in a campaign against the Babylonians.

The coming of the Greeks in $332 \mathrm{BC}$ changed the nationality of the invading armies, but little else, for Megiddo and the Jezreel Valley remained a "contested periphery". Alexander the Great and his army almost certainly passed right by Megiddo, apparently without needing to fight a battle, while conquering Syria-Palestine and Egypt. Following Alexander's death in 323 $\mathrm{BC}$, the lands which he had conquered were split up among several of his generals. This gave rise to the Antigonid, Seleucid, and Ptolemaic empires during the ensuing Hellenistic period from 323 to 30 BC. The Seleucids in Syria and the Ptolemies in Egypt were almost constantly at war with each other, for each had their eye on the other's territory. It is during this period, in the time of Antiochus III and Ptolemy IV, that the Jezreel Valley once again saw bloodshed as a result of its status as a "contested periphery," during the battle at Mount Tabor which occurred in 218 BC.

Blood was again spilled in this "contested periphery" during the battles fought in the Jezreel Valley between rival Islamic forces, such as when the Ikhshidids of Egypt fought the Abbasids of Mesopotamia at Lejjun by Megiddo in AD 940, and then took on the Hamdanids of Northern Syria and Mesopotamia in the same area just six years later, in AD 946. The same goes as well for the Byzantine invasion of the Jezreel Valley in AD 975, when it was held by Fatimid forces from Egypt, and for Saladin and the Crusaders, who were fighting to extend the Islamic Empire and the holdings of Christian Europe respectively when they met in the Jezreel Valley in AD 1182, 1183, and again in 1187. When the Mamlukes from Egypt and the Mongols from Asia fought at 'Ayn Jalut in the Jezreel Valley in AD 1260, both sides were fighting to extend their empires to include this contested region, as was Napoleon when his French forces took on those of the Ottoman Empire at the Battle of Mount Tabor in AD 1799. During World War I, the Jezreel Valley became a "contested periphery" for both the British Empire (actually the Allies as a whole) and the Ottoman Empire, culmi- 
nating in Allenby's famous battle at Megiddo in September 1918 which so deliberately and successfully mimicked Thutmose III's tactics in the same area 3,400 years previously.

In short, if one looks at the battles fought at Megiddo and in the Jezreel Valley from the mid-first millennium BC, when the kingdoms of Israel and Judah were in their last years of existence, up until AD 1948, when the State of Israel was established and the Israelis began actively defending their territory, it is clear that most of the conflicts were fought by rival empires from outside the area, each of which claimed or wanted the region for its own. Apart from a brief period during the first centuries BC and AD, when the local Jewish population rose up several times against late Hellenistic and Roman rulers, we are looking at a period of more than two and half millennia during which at least seventeen different battles were fought because Megiddo and the Jezreel Valley fell into the category of a contested periphery."

The Jezreel Valley can be compared to the meeting place of two tectonic plates, where the stress and strain frequently result in cataclysmic, earth-shaking events of immense magnitude, whose reverberations are felt far away, both geographically and temporally. Why is this? What is it about this region that attracts battles and has prompted such a continuous state of warfare over the past 4,000 years? Although Megiddo and the Jezreel Valley were valuable in their own right, of course, what made them even more desirable was the fact that they were literally always in the way of anyone or anything wishing to proceed from north to south or from south to north in Syria-Palestine, regardless of the period or era in question. The Jezreel Valley was, in short, always a major crossroads, commanding also routes leading from east to west and west to east. Thus, whosoever controlled the Jezreel Valley militarily, whether it was through occupation of Megiddo, Jezreel, Mount Tabor, or any of the other prominent cities and towns which rose and fell through the millennia in this valley, by default also controlled it economically and politically, vis á vis the trade and traffic through the area, be it of warriors or merchants. It is not difficult to see why this region was so desirable for so many centuries to so many different peoples.

However, there is also something about the Jezreel Valley, a geographical "je ne sais quoi," which seems to bring great conquerors together through time and space in a way that no other circumstance has or can. Napoleon supposedly once said, "There is no place in the whole world more suited for war than this... all the armies of the world could maneuver for battle here... [It is] the most natural battleground of the whole earth." Indeed, few other areas of the world can claim to have seen so many different armies, and so many famous leaders, march through their lands over such a continuous period of time. One might well paraphrase the immortal words of Sir Winston Churchill; "Never in the field of human conflict have so many fought so often over so little space."

It may be that a continuous stream of armies should actually be expected as a natural occurrence in a region such as the Jezreel Valley, which sits astride a important route where different geographical, economic and political world-systems came into frequent contact, and which may have grown wealthy in part by exploiting its international connections. In World systems theory, one might say that, like any prosperous city on a busy military and mercantile route, such a desirable peripheral region would likely gain the covetous gaze of rulers in one or more neighboring cores and thus would be highly contested. Apparently, Megiddo had insufficient hinterland and natural resources to become a core on its own, but it certainly became a major entrepôt and an important periphery, waxing and waning in a complex series of cycles with the nearby major players and world-systems who competed for control of this lucrative region each time they pulsed outward and bumped into each other (Hall, personal communication; 1999: 9-10).

If an area is truly a "contested periphery," one might well expect to find frequent shifts in key trading partners, if the region regularly changed hands or political affiliations. The battles fought in the area might serve as markers of change in this core orientation or, alternatively, as markers for a lack of change if the existing core power was successful in retaining control (Allen, personal communication). Such shifts may show up archaeologically, given that local elites frequently mimic their core counterparts. Archaeological indicators might include types of elite goods imported (Schortman and Urban 1994; Urban and Schortman 1999), changes in writing and weight systems, and reorganization of palaces or even whole cities (such as happened in Stratum III at Megiddo, when the Neo-Assyrian conquerors laid out a new set of palaces and administrative buildings). These shifts, however, will only be assessable if these kinds of distinctive features are left as extant evidence in the archaeological record, which is frequently not the case. 
Moreover, such changes can also take place without the region changing hands or political affiliations, particularly if the area, like the Jezreel Valley, is located on a major trade route and generally evinces a mixing of competing core cultures in terms of the elite goods found at key settlements such as Megiddo. Indeed, Megiddo and the Jezreel Valley also fit the definition of an entrêpot or a crossroads area, providing a zone of cross-fertilization for the ideas, technology, and material goods which came into and crossed through the region (Hall, personal communication; cf. Teggart 1918, 1925; Bronson 1978; Bentley 1993). If, however, the area is not located along a major trade route, this is a moot point, for it is unlikely to give rise to a major trading center such as Megiddo, Tyre, Ugarit, or even the cities located along the Silk Route.

In the case of Megiddo, though, its prime location as a choke point along the main geographical highway connecting two core regions not only allowed it to serve as an entrêpot and a crossroads area, but in the process also caused it to become a major focus for conflicts and a bone of contention for the core regions on either side. As a result, for much of its history the Jezreel Valley was quite literally the perfect example of a geographical and political "contested periphery" in every sense of the phrase. However, if this idea of a "contested periphery," as defined originally by Allen and refined herein, is to become a viable part of World systems theory, it must be able to explain more than a single case.

Indeed, there are any number of additional examples of cores in the ancient world which were in competition for the same peripheries. For example, the Trojan plain and the neighboring regions bordering the Hellespont on the Aegean coast of Turkey could be seen as a "contested periphery" between Mesopotamia and the Mediterranean at a number of different times during antiquity. Other potential suggestions could encompass Dilmun in the Persian Gulf region, areas in the North American Midwest or Southwest, and perhaps various regions in Mesoamerica.

It is the Kephissos River Valley, and the nearby plains commanded by Boeotian Thebes, in central Greece which springs most readily to mind, however, at least to this historian of the ancient Greek and Eastern Mediterranean worlds. This valley saw any number of battles fought in and around the important settlement of Thebes from the time of the Mycenaeans in the second millennium BC, through the total destruction of the city by Alexan- der the Great in the fourth century BC, right up until the modern era and the German invasion during World War II. The "contested periphery" model can be used to explain Boeotian Thebes and the Kephissos Valley at various times in history, in much the same way as it has been used above to discuss Megiddo and the Jezreel Valley. Like the Jezreel Valley in Israel, the Kephissos Valley in Greece was literally a natural geographical highway which was often the only practical choice for both warriors and merchants to use when traveling from north to south or south to north in Greece. It lay on the periphery of Thessaly and Macedonia to the north and Attica and the Peloponnese to the south, as well as Italy to the west and Byzantium/ Constantinople to the east, and was an area both claimed and contested on and off throughout history by the powers in these core regions lying to each side. Additional research currently underway by the present author should determine just how well the term "contested periphery" may be applied to this area of Boeotian Thebes and the Kephissos River Valley in central Greece at particular times during its history.

A key question which remains to be asked is exactly what is to be gained by acknowledging that Megiddo and the Jezreel Valley, and seemingly other areas of the ancient and modern world as well, served as a contested periphery" throughout much of its history? First and foremost, we can expand the definitions of a "contested periphery" previously suggested by Allen and by Hall and Chase-Dunn to include the additional criterion that such a region is likely to have been a ripe battle zone. If the area does not have sufficient hinterland, as was the case with Megiddo and the Jezreel Valley, it cannot become a core in its own right, and probably cannot even become a semiperiphery (Hall, personal communication). What keeps such an area a"contested periphery," rather than being permanently incorporated by one of the flanking cores, is that for whatever reason(s) neither of the neighboring core regions is able to fully incorporate it as its own periphery. No empty buffer region is thus able to develop between the two cores, due to insufficient distance, and thus the area in question remains both enticing and contested, despite repeated attempts to incorporate it. As stated above, there are undoubtedly other areas in the world which fit this expanded definition of a "contested periphery;" it will be of interest to see if other scholars are willing or able to make use of this concept and incorporate it further into World systems theory. 


\section{REFERENCES}

Allen, M.J. (1997). Contested Peripheries: Philistia in the Neo-Assyrian World-System. Ph.D. Dissertation, University of California, Los Angeles. Ann Arbor: University Microfilms.

Bentley, J.H. (1993). Old World Encounters: Cross-Cultural Contacts and Exchanges in PreModern Times. New York: Oxford University Press.

Berquist, J.L. (1995a). Judaism in Persia's Shadow: A Social and Historical Approach. Minneapolis: Fortress Press.

Berquist, J.L. (1995b). “The Shifting Frontier: The Achaemenid Empire's Treatment of Western Colonies," Journal of World-Systems Research, http://jwsr.ucr.edu/ 1:1-38.

Bronson, B. (1978). "Exchange at the Upstream and Downstream Ends: Notes Toward a Functional Model of the Coastal State in Southeast Asia," in Economic Exchange and Social Interaction in Southeast Asia: Perspectives from Prehistory, History, and Ethnography: 39-52, K.L. Hutterer (ed.). Ann Arbor: The University of Michigan.

Chase-Dunn, C. and Hall, T.D. (1997). Rise and Demise: Comparing World-Systems. Boulder CO: Westview Press.

Cline, E.H. (2000). The Battles of Armageddon: Megiddo and the Jezreel Valley from the Bronze Age to the Nuclear Age. Ann Arbor: University of Michigan Press.

Fisher, C.S. (1929). The Excavation of Armageddon. Oriental Institute Communications No. 4. Chicago: University of Chicago Press.

Hall, T.D. (1999). "World-Systems and Evolution: An Appraisal," in World-Systems Theory in Practice: Leadership, Production, and Exchange: 1-23, P.Nick Kardulias (ed.). Lanham, MD: Rowman \& Littlefield Publishers, Inc.

Schortman, E.M., and Urban, P. (1994). "Living on the Edge: Core/Periphery Relations in Ancient Southeastern Mesoamerica," Current Antbropology 35: 401-430.

Urban, P.A., and Schortman, E.M. (1999)."Thoughts on the Periphery: The Ideological Consequences of Core/Periphery Relations," in World-Systems Theory in Practice: Leadership, Production, and Exchange: 125-52, P. Nick Kardulias (ed.). Lanham, MD: Rowman \& Littlefield Publishers, Inc.

Teggart, F.J. (1918). The Processes of History. New Haven: Yale University Press.

Teggart, F.J. (1925). Theory of History. New Haven: Yale University Press. 